Tjalling C. Koopmans Research Institute

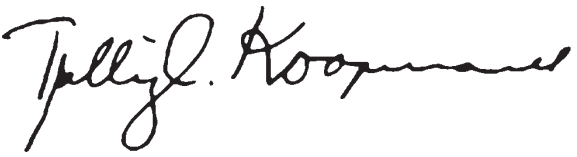

Discussion Paper Series nr: 07-24

\title{
European Economic Integration and (A)symmetry of Macroeconomic Fluctuations
}

Claire Economidou, Clemens Kool 


\section{Tjalling C. Koopmans Research Institute Utrecht School of Economics \\ Utrecht University}

Janskerkhof 12

3512 BL Utrecht

The Netherlands

telephone $\quad+31302539800$

fax $\quad+31302537373$

website www.koopmansinstitute.uu.nl

The Tjalling C. Koopmans Institute is the research institute and research school of Utrecht School of Economics.

It was founded in 2003, and named after Professor Tjalling C. Koopmans, Dutch-born Nobel Prize laureate in economics of 1975.

In the discussion papers series the Koopmans Institute publishes results of ongoing research for early dissemination of research results, and to enhance discussion with colleagues.

Please send any comments and suggestions on the Koopmans institute, or this series to s.mook@econ.uu.nl

ontwerp voorblad: WRIK Utrecht

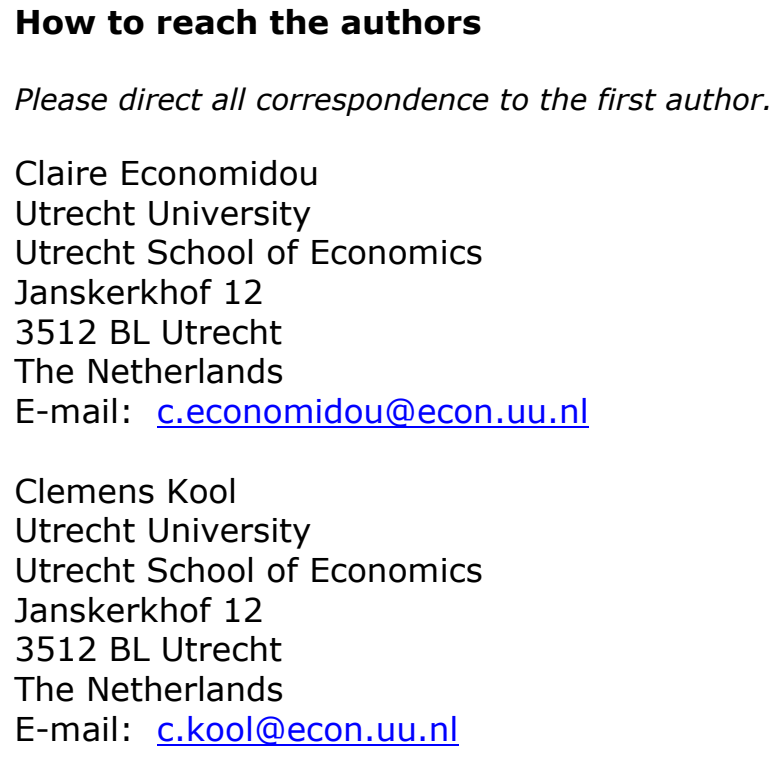


Utrecht School of Economics

Tjalling C. Koopmans Research Institute

Discussion Paper Series 07-24

\title{
European Economic Integration and (A)symmetry of Macroeconomic Fluctuations
}

\author{
Claire Economidou ${ }^{a}$ \\ Clemens Kool ${ }^{\mathrm{b}}$ \\ aUtrecht School of Economics \\ Utrecht University \\ bUtrecht School of Economics \\ Utrecht University
}

October 2007

\begin{abstract}
This paper empirically investigates output and consumption asymmetries in the Eurozone and enlarged EU over the period 1992-2007, and their consequences for monetary policy. Our results reveal that the introduction of the euro has little impact on output asymmetry so far; however, it has led to somewhat greater consumption smoothing. The UK, Denmark and Sweden are no less asymmetric than the average Eurozone member state and could probably enter the EMU without significant macroeconomic costs. New EU member states are diverse but display higher output and, in particular, consumption asymmetries. This warrants caution against too quick expansion of the EMU.
\end{abstract}

Keywords: Integration, Macroeconomic Asymmetries, Welfare Gains, Risk Sharing, Euro

JEL classification: E32, F15 


\section{Introduction}

The 'new' monetary Euro regime and the growing integration of European markets have dominated monetary policy discussions in Europe in recent years. Of particular interest and importance among economists and EU policy makers has been the (a)symmetry of macroeconomic fluctuations as a crucial factor in judging the desirability of economic and monetary integration.

From a static point of view, it has been argued that the cost of joining a monetary union and abandoning independent national currencies would be low if countries are characterized as an optimal currency area (OCA). That is, if they exhibit similar economic structures and, consequently, synchronized (symmetric) business cycles ${ }^{1}$. In that case, the absence of an independent national monetary policy does not need to be a major concern, as country-specific (idiosyncratic) shocks are relatively unimportant.

However, the process of economic and monetary integration itself can also affect the symmetry of macroeconomic fluctuations ${ }^{2}$. Similar economic policies (Coe and Helpman, 1995), tighter international trade links (Krugman, 1993; Frankel and Rose, 1998), and better risk sharing due to integrated financial markets and government transfers (Obstfeld and Rogoff, 1996; Sorensen and Yosha, 1998; Kalemli-Ozcan et al., 2001) all can jointly shape and change the post-integration patterns of macroeconomic fluctuations.

As it has been argued in the substantial literature developed in this field, both higher and lower output asymmetry may result from increased economic and financial integration. While more similar policies, reduced trade barriers and technology spillovers

\footnotetext{
${ }^{1}$ The debate about the costs and the benefits of an OCA dates back to Mundell (1961). See De Grauwe (1992) for an exposition.

${ }^{2}$ Frankel and Rose (1998) stress the 'endogeneity' of (optimal) currency areas.
} 
all add to increased output similarity, increased financial integration combined with lower trade barriers, through increased industrial specialization, may result in increased output dissimilarity. The degree of asymmetry in macroeconomic fluctuations across the Eurozone countries and the direction in which the asymmetry develops is an important matter for the European Central Bank (ECB), High output asymmetry across member countries may create some strain on monetary policy and ultimately on the ECB's independence.

Therefore, a first issue we address in this paper is to what extent the period following the introduction of the euro (1999-2007) already shows a trend towards either increasing or decreasing output asymmetry compared to the period before (1992-1998). Although the euro period is still short, the empirical evidence may shed some light on the direction and speed of changes in output patterns.

In addition, we expand the analysis to consider developments in consumption asymmetry across the Eurozone members. The asymmetry of consumption has important implications for the stability of the European Monetary Union (EMU). Arguably, output asymmetry may put some pressure on the ECB's common monetary policy. However, if countries care more about their consumption rather than their output, this concern may be overstated. In a union with sufficient integrated financial markets and risk sharing mechanisms, increased output asymmetry-though perhaps inconvenient for the ECB monetary policy-does not necessary lead to welfare losses and instability, if consumption is hedged against idiosyncratic shocks (Sorensen and Yosha, 1998). Therefore, we also examine whether consumption asymmetry has decline in the Eurozone after the introduction of the euro due to better risk sharing, via international diversification of financial assets through removing costs of currency hedging and greater transparency. 
Second, we recognize that the Eurozone is not in its steady state yet in terms of participating countries. Consequently, we empirically examine whether there are substantial differences in asymmetry patterns when the Eurozone (EU-12) expands to EU-15 (Eurozone and three long-standing members), EU-27 (long-standing members and twelve new members) and further to EU-29 (EU-27 and two candidate countries) for the period 1992-2007. We use these results to reflect on the challenges that the ECB monetary policy is expected to face in the future.

To empirically implement our objectives, we follow Kalemli-Ozcan et al. (2001) and utilize the potential welfare gain of a country joining a monetary union and the risk sharing arrangement it offers as a measure of asymmetry of output and consumption shocks ${ }^{3}$. This utility gain is expressed in terms of consumption certainty equivalence. The rationale behind this is the more asymmetric the output (consumption) shocks of an individual country relative to the group are, the larger the gains it receives from and offers to other group-members.

The sample considered in our analysis includes twenty-seven EU member states and two candidate countries over the period 1992-2007. In comparison with previous related literature, our paper uses a significantly increased sample of data, in terms of number of countries, while the period under investigation is stretched to include very recent observations. Further, unlike past studies, the empirical analysis of this paper is based on quarterly data.

Our findings reveal that further and deeper economic integration in the Eurozone has had no significant impact on the pattern of output asymmetry yet, although for most countries absolute output growth variability has been declined. However, consumption

\footnotetext{
${ }^{3}$ This approach has been also followed by Kalemli-Ozcan et al. (2005) and Demyanyk and Volosovych, (2007).
} 
asymmetry appears to be, on average, smaller than that of output and declining after the introduction of the euro, in 1999. Furthermore, we find no significant difference in output asymmetry and consumption risk sharing between the Eurozone and the three noneuro members of the EU-15. Contrary to what it is often alleged, the entry of, for instance, the UK in the Eurozone would not cause any further burden on the ECB or decrease the homogeneity, as measured by the overall degree of output or consumption asymmetry, in the Eurozone.

Findings are somewhat different, however, for the enlarged EU. In the EU-27 and EU-29 output asymmetries (potential welfare gains) appear to be considerably larger for the new than for the long-standing members, causing output asymmetry in the union, as a whole, to rise considerably. Diversity in asymmetry patterns within the new member states/candidate countries is substantial, too. While the output asymmetry of, for instance, the Czech Republic and Slovenia is close to the average of the old EU members, asymmetries for members like Romania, Bulgaria and candidate countries, Croatia and Turkey, are much larger. This finding suggests that entry into the Eurozone should be realized on an individual basis, to limit the challenges for the ECB monetary policy making. The evidence on consumption risk sharing in the EU-27 and EU-29 reveals that almost all new members/candidate countries have less consumption risk sharing than the old EU members have. As a result, any consequence of asymmetric output shocks will have to be borne, to a larger extent, by the domestic country. Clearly, the advantages of financial integration in this respect need to be further developed.

The rest of the paper is organized as follows. Section 2 briefly summarizes the relevant literature. Section 3 presents the methodology and describes the data. Section 4 discusses the empirical findings. Section 5 concludes. 


\section{Related Literature Review}

The creation of the EMU has revived the interest in (optimal) currency unions and spurred an extensive body of literature, in which the symmetry of macroeconomic fluctuations occupies a central position.

The empirical literature on the desirability of the EMU has typically focused on comparing within-country to cross-country correlations. Early studies in this literature (De Grauwe and van Haverbeke, 1993; Bayoumi and Eichengreen, 1993) as well as a number of more recent (Fatas, 1997; Wynne and Koo, 2000; Forni and Reichlin, 2001; Clark and van Wincoop, 2001) compare either the variations of aggregate output/employment data across EU regions to variations of aggregate output/employment across EU countries, or the correlations of employment/output across EU countries to US regions since US is a successful currency union and serves as a benchmark for EMU.

A companion literature decomposes further the sources of within-country and cross-country fluctuations into common national-specific, region-specific, and industryspecific components. Stockman (1988) and a number of subsequent studies assess the relative importance of country-specific versus industry-specific shocks by examining the sources of fluctuations at both aggregate level (Costello, 1993; Drummen and Zimmermann, 1992; Heston and Rouwenhorst, 1994; Norrbin and Schlagenhauf, 1996) and disaggregate level (Helg et al., 1995), using a variety of statistical models and methodologies ${ }^{4}$. Overall, the findings of these two strands of literature suggest that shocks are more symmetric across the US regions than in Europe and that countryspecific sources of variation typically dominate industry-specific factors.

\footnotetext{
${ }^{4}$ For a survey, see Clark and Shin (2000).
} 
A considerable amount of work has been also devoted in explaining what determines the observed business-cycle correlations. Several mechanisms have been proposed in the literature. Similar economic (and mainly monetary) policies and supply shocks via technology and knowledge spillovers have been identified as potential sources of symmetry in fluctuations (Coe and Helpman, 1995).

International trade in goods has been another mechanism that shapes the symmetry of fluctuations. Other things being equal, tighter international trade links could spur inter-industry specialization, rendering the business cycles among members less synchronized (Kenen, 1969; Krugman, 1993). However, lower trade barriers could also stimulate intra-industry specialization leading to less asymmetric fluctuations since more trade could allow demand shocks to be spread across countries. This argument finds empirical support from Frankel and Rose (1998).

Increased financial integration among members of a monetary union and trade in financial assets sets yet another mechanism at work, that of risk sharing through crossownership of (productive) financial assets. An active literature explores the role of market institutions (capital and credit markets) in providing international risk sharing (Obstfeld, 1994; Baxter and Crucini, 1995; Asdrubali et al., 1996; Sorensen and Yosha, 1998) and its implications on income insurance and consumption smoothing ${ }^{5}$. An important implication is that better risk sharing would result in greater specialization. In turn, dissimilarities in the manufacturing structure would result in higher output asymmetry $^{6}$.

\footnotetext{
${ }^{5}$ Fiscal institutions can also affect risk sharing by providing cross-border income insurance via taxtransfers and grants allocation to specific countries. See Obstfeld and Rogoff (1996) for a survey. ${ }^{6}$ Specialization in production could lead to welfare losses due to output risk in the absence of insurance at the macro level. However, with increasing integration of financial and good markets, a country can combine an increase in specialized production with insurance against asymmetric output shocks through
} 
This premise has been substantiated empirically by Kalemli-Ozcan et al. (2001) and Kalemli-Ozcan et al. (2003). Kalemli-Ozcan et al. (2001) regress a utility-based measure of fluctuations asymmetry on indices of manufacturing specialization for US states and OECD countries over the period 1963-1994. They establish a positive and significant link between production specialization and output asymmetry. In addition, Kalemli-Ozcan et al. (2003) establish a positive link between risk sharing and production specialization. This evidence allows them to conclude that increased financial integration and risk sharing increases specialization which in turn increases output asymmetry. However, their conclusion is strongly dependent on the US state evidence. For OECD countries, the link between output specialization and asymmetry appears rather weak, suggesting that OECD countries remain much more diversified in their economic production structure than US states.

Using similar methods, Kalemli-Ozcan et al. (2005) compare the asymmetry of GDP and GNP fluctuations in fourteen EU countries and the US over the period 19832000. Their results support a steep reduction in GDP asymmetry over time, both in the EU and US. However, factor income flows do not appear to smooth GNP across EU countries, suggesting that EU capital markets are as yet less integrated than internal US capital markets.

In the same tradition, Demyanyk and Volosovych (2007) evaluate the potential risk sharing benefits that would accrue to ten newly acceded EU members over the period 1994-2003 in a situation of complete integration and risk sharing. For large, longstanding members of the EU the welfare gains are found to be negligible while new members appear to benefit the most. Further, they argue that the process of integration 
within the enlarged EU would lead to further synchronization of macroeconomic fluctuations across member countries and depletion of risk sharing opportunities.

The present study relies on the utility-based asymmetry measure proposed by Kalemli-Ozcan et al. (2001), and employed by subsequent studies, in assessing the asymmetries in output and consumption fluctuations for the EU countries. Describing the construction of such measure and the nature of the data used in our analysis is the aim of the next section.

\section{Methodology and Data}

\section{A Utility-based Measure of Asymmetry}

The measure we use to assess the degree of asymmetry in macroeconomic fluctuations is based on potential welfare gains from risk sharing in a monetary union. To construct such a measure, Kalemli-Ozcan et al. (2001) consider a group of stochastic endowment economies inhabited by representative risk adverse agents who derive utility by consuming a homogenous, non-storable good ${ }^{7}$. Under simple assumptions, including symmetric information, no transaction costs, identical CRRA (and therefore logarithmic) utility and rate of time preferences, perfect risk sharing among countries in the group implies $c_{i t}=k_{i} g d p_{t}$, where $c_{i t}$ is the per capita consumption of country $i, g d p_{t}$ is the groupwide (aggregate) per capita GDP (endowment) and $k_{i}$ a fixed portion of country $i$ 's consumption of the group-wide GDP.

Then, for every country $i$ in the group, the expected utility of consuming country's own per capita output ( $\left.g d p_{i t}\right)$ under autarky is compared to consuming a fixed portion of group's per capita output $\left(k_{i} g d p_{t}\right)$ under perfect risk sharing. The difference

\footnotetext{
${ }^{7}$ Kalemli-Ozcan et al. (2001) build on previous work by Obstfeld (1994) and Wincoop (1994).
} 
represents potential utility gains derived from a permanent increase in consumption when country $i$ moves from autarky to perfect risk sharing.

Assuming that country-level endowment is well-described by a random walk and the endowments' growth rates are normally distributed, the country-by-country measure of welfare gain, $G_{i}$, is calculated as the utility equivalent of a permanent increase in consumption from $G D P_{i 0}$ in autarky to $G D P_{i 0}\left(1+G_{i}\right)$ under perfect risk sharing in the group.

These potential welfare gains capture the degree of country-level asymmetry. The rationale behind is that the more a country can gain from sharing idiosyncratic risk with other countries in the group, the more asymmetric her shocks are with respect to those of the group. Kalemli-Ozcan et al. (2001), express the country-specific asymmetry measure (potential welfare gains) for the case of the logarithmic utility, $u\left(c_{i t}\right)=\log \left(c_{i t}\right)$, as follows:

$$
G=\frac{1}{\delta} \times\left(\frac{1}{2} \sigma^{2}+\frac{1}{2} \sigma_{i}^{2}-\operatorname{cov}_{i}\right)
$$

where $\delta$ is the intertemporal discount rate, $\sigma^{2}$ is the variance of growth rate of real per capita aggregate (group-wide) endowment, $\sigma_{i}^{2}$ is the variance of growth rate of country $i$ 's real per capita endowment, and $\operatorname{cov}_{i}$ the covariance of country $i$ 's endowment with the aggregate endowment.

The intuition of the asymmetry measure based on the log-utility function is simple and straightforward: the higher the variance of the aggregate endowment of the group, keeping the variance of individual country $i$ constant, the more willing the group is to 'pay' country $i$ for joining the risk sharing arrangement; the higher the variance of 
country $i$, the more the country gains in terms of risk sharing by joining the group; and the lower the covariance between country's $i$ endowment and aggregate endowment, the more country $i$ is compensated for providing insurance to the group by stabilizing the aggregate endowment.

Based on equation (1), we calculate two measures of asymmetry: An output-based asymmetry measure $\left(G^{G D P}\right)$ and a consumption-based asymmetry measure $\left(G^{C O N}\right)$. The former represents the 'total' potential welfare gains obtained when a country moves from financial autarky to full risk sharing output allocation while the latter represents the 'unexploited' welfare gains from risk sharing when a country moves from the level of consumption observed in the data to full risk sharing consumption allocation.

To assess the robustness of our results, we further estimate the two countryspecific asymmetry measures with the CRRA utility function. Kalemli-Ozcan et al. (2001) provide a closed-form solution for the welfare gains from risk sharing for the case of the CRRA utility function ${ }^{8}$ :

$$
\begin{aligned}
C R R A= & \log \left(\delta-(1-\gamma) \mu-\frac{1}{2}(1-\gamma)^{2} \sigma^{2}\right)-\log \left(\delta-\left(\mu-\mu \gamma+\frac{1}{2} \sigma_{i}^{2}+\frac{1}{2} \gamma^{2} \sigma^{2}-\gamma \operatorname{cov}_{i}\right)\right) \\
& +\frac{1}{1-\gamma} \log \left(\delta-(1-\gamma) \mu-\frac{1}{2}(1-\gamma)^{2} \sigma_{i}^{2}\right)-\frac{1}{1-\gamma} \log \left(\delta-(1-\gamma) \mu-\frac{1}{2}(1-\gamma)^{2} \sigma^{2}\right)
\end{aligned}
$$

where $\gamma$ is the risk aversion parameter and $\mu$ the growth rate of the endowment.

In the empirical implementation, the parameters $\sigma^{2}, \sigma_{i}^{2}$ and $\operatorname{cov}_{i}$ are estimated using country-level growth rates of real per capita output, for the output-based asymmetry measure, and country-level growth rates of real per capita consumption, for the consumption-based asymmetry measure. The intertemporal discounting factor, $\delta$, is equal to 0.005 (for quarterly observations).

\footnotetext{
${ }^{8}$ For the derivation of the asymmetry measure, see the appendix of Kalemli-Ozcan et al. (2001).
} 


\section{Data}

We use quarterly gross domestic product (GDP) and final consumption expenditures data for twenty-seven EU member-states and two candidate countries over the period 1992.Q1-2007.Q1 ${ }^{9}$. The OECD (2007) Quarterly National Accounts provides seasonally adjusted and adjusted by working days GDP and consumption data in millions of euro for all EU member-states and candidate countries. However, for some countries in our sample (e.g., Bulgaria, Croatia, Luxemburg, Romania and Turkey) data were not provided seasonally adjusted. We employ the Census X-12 Arima method to seasonally adjust the data ${ }^{10}$. Further, for some countries (e.g., Croatia, Ireland, Luxembourg, Malta, Portugal and Romania), output and consumption data are not available for the initial years of our sample period; we linearly extrapolate using STATA's extrapolation function to make up for the missing data.

Since our asymmetry measures are utility-based, in order to convert our variables into real terms, we deflate by the consumer price index $(\mathrm{CPI})$. In this respect, measured output reflects consumption purchasing power. Data on CPI (base year 2000) are obtained from the International Monetary Fund (2007) International Financial Statistics. To calculate per capita output and consumption, we use the OECD (2007) Quarterly National Accounts to extract data on total population. Finally, growth rates of real per

\footnotetext{
${ }^{9}$ The EU member-states are: Austria, Belgium, Denmark, Finland, France, Germany, Greece, Ireland, Italy, Luxemburg, Netherlands Portugal, Spain, Sweden, U.K. (long-standing members), Cyprus, Czech Republic, Estonia, Hungary, Latvia, Lithuania, Malta, Poland, Slovakia, Slovenia (members as of 1 May 2004), Bulgaria and Romania (members as of 1 January 2007). The two candidate members are: Croatia and Turkey. Croatia applied for EU membership on 21 February 2003 and Turkey on 14 April 1987. The EU officially launched accession negotiations with Croatia and Turkey at the General Affairs Council in Luxemburg on 3 October 2005.

10 The Census X-12 Arima method developed by the United States Bureau of Labor Statistics use ARIMA (Auto-Regressive Integrated Moving Average) process for forecasting trends. We also considered the TRAMO-SEATS method widely used by EUROSTAT for seasonally adjusting monthly and quarterly data for member countries of the European Union. Both methods give virtually identical results in our case.
} 
capita variables are calculated as first differences of the natural log of real per capita level values.

Our first goal is to investigate whether the introduction of the euro through deeper financial integration has affected output and consumption asymmetry patterns in the Eurozone $^{11}$. To this end, we split the sample period into two sub-periods, 1992.Q11998.Q4 and 1999.Q1-2007.Q1 ${ }^{12}$. Table 1 contains the summary statistics of per capita growth rates of GDP and final consumption expenditures of the Eurozone members over the two sub-periods. ${ }^{13}$ The statistics show that in both periods high output and consumption volatility is reported by Ireland, Greece, Luxemburg and Finland. Except for Ireland and Spain, output volatility decreases over time. Consumption volatility also declines in all countries except in the cases of Greece and Ireland. The last column of the table captures the effectiveness of smoothing out consumption at the domestic level, relative to output volatility. In principle, higher risk sharing should result in smoother consumption relative to output volatility. For most countries, and on average, relative consumption volatility falls somewhat. Exceptions are Belgium, Greece, Luxembourg and Spain.

(Table 1 goes about here)

The second part of our analysis focuses on asymmetry and potential gains in risk sharing in the enlarged EU. We therefore, stepwise, broaden the group of countries under

\footnotetext{
11 The Eurozone group includes Austria, Belgium, Finland, France, Germany, Greece, Ireland, Italy, Luxemburg, Netherlands Portugal, Spain (EU-12) and Slovenia. On 1 January 2001, Greece became the 12 th country to adopt the common currency after it fulfilled all requirements. Euro banknotes and coins have been in circulation since 1 January 2002 for all the Eurozone member countries except Slovenia. Slovenia adopted the euro on 1 January 2007. Since 2007 (first quarter) is the last observation in our sample, the Eurozone in our analysis consists of twelve countries of the euro-area, the EU-12.

${ }^{12}$ On 31 December 1998, the European Currency Union (ECU) exchange rates of the Eurozone members were fixed and the value of the euro, which then superseded the ECU, was established.

${ }^{13}$ A caveat with respect to the interpretation of the statistics applies due to the relatively short samples in which individual observations may have significant impact.
} 
consideration from the EU-15 (Eurozone and three long-standing members), to the EU-27 (long-standing members and twelve new members) and finally to the EU-29 (EU-27 and two candidate countries). Table 2 reports summary statistics per country for the overall period 1992.Q1-2007.Q1. For comparison, Table 2 begins with summary statistics for the Eurozone.

The statistics show that mean growth rates and volatility of output and consumption are virtually the same for the Eurozone countries and the EU-15. However, new EU members and candidate countries have considerable higher and more volatile growth rates than the old (EU-15) members. Among the new member states, the Baltic states (Estonia, Latvia, Lithuania) exhibit the highest growth rates and volatility in output and consumption. Quite volatile patterns of output and consumption are also those of Bulgaria, Croatia and Turkey. The last column of the table reports the relative volatility ratio. Results show that in some cases the relative volatility measure is higher than one. The latter, could imply negligible (or even lack of) consumption risk sharing at domestic level (Prasad et al., 2003) ${ }^{14}$. Overall, it appears that as the EU expands from EU-15 to EU-27 and further to EU-29 both absolute and relative volatility increase substantially.

(Table 2 goes about here)

\section{Empirical Results}

In this section, we investigate the asymmetry patterns in output and consumption, using the approach set out by Kalemli-Ozcan et al. (2001) and relate our findings to the challenges for monetary policy making faced by the ECB. In section 4.1, we consider the impact of the introduction of the euro on output and consumption asymmetry in the

\footnotetext{
${ }^{14}$ Consumption data might well be affected by taste shocks (Stockman and Tesar, 1995), which could increase the volatility of consumption even in the presence of a substantial amount of risk sharing.
} 
Eurozone. In section 4.2, we consider the impact of expanding the EU (from the Eurozone to EU-29) on output and consumption asymmetry.

\subsection{Eurozone}

First, we discuss the asymmetry patterns of output and subsequently those for consumption. Table 3 presents the output results, both for the whole sample period and the two sub-periods: 1992.Q1-1998.Q4 (before the euro) and 1999.Q1-2007.Q1 (after the euro). Column (3) contains the output asymmetry estimates, calculated with the log utility. ${ }^{15}$ Over the whole period, the countries with the highest degree of asymmetry, and therefore the largest potential welfare gains in the Eurozone, are Ireland, Greece, Luxemburg, followed by Portugal and Finland. On the opposite side, are France, Austria, Germany, followed by Italy and the Netherlands. Overall, it appears that small, peripheral members of the Eurozone are the most asymmetric in terms of output fluctuations while large, core members are the least asymmetric. From columns (1) and (2), we observe that countries which gain the most from better risk sharing are those which exhibit high volatility of output growth and low covariance with the rest countries of the Eurozone.

We further consider output asymmetry before and after the introduction of the euro in the second and third panel of table 3, respectively. The evidence demonstrates that the countries displaying the largest asymmetry are roughly the same in the first and second sub-period. Also, on average, output asymmetry has remained pretty much unchanged with the introduction of the euro.

(Table 3 goes about here)

\footnotetext{
${ }^{15}$ Asymmetry measures based on more general CRRA utility function are reported in column (4) and qualitatively provide the same evidence. Consequently, we do not discuss these separately.
} 
We now turn our attention to the pattern of consumption-based asymmetry measure. Results are reported in Table 4, which has the same lay-out as Table 3. For the whole period, Greece, Ireland and Luxembourg are the countries displaying the highest degree of asymmetry and consequently have the highest potential welfare gains. Note that these countries had also the highest output asymmetry estimates. The gains result mainly from the combination of high consumption growth variability and low correlation with the Eurozone group. On average, consumption variances in Table 4 are smaller than output variances in Table 3, implying smaller welfare gains from risk sharing in consumption.

Next, we investigate the impact of the introduction of the euro, and the hypothesized deeper integration, on consumption asymmetry. Dividing the period into two sub-periods and relying on estimates reported in columns (3) and (4) of Table 4, we find that in both sub-periods Luxembourg, Ireland and Greece are the most asymmetric member-states, followed by Spain, Finland and Portugal. These countries show the highest variability of consumption and the lowest correlation or even counter-cyclicality (e.g., Finland, Greece) relative to aggregate consumption ${ }^{16}$.

On average, consumption asymmetry falls between the first and second subperiod. Although the absolute magnitude of the fall is limited, in percentages it is substantial with a reduction in the second period compared to the first of more than 20 percent. This was mainly due to less variation in consumption growth during the second period. While some caution is required due to the small sample, our results give suggestive evidence that the introduction of the euro through deeper economic integration

\footnotetext{
${ }^{16}$ For robustness, we also computed asymmetry measures based on gross national disposable income (Greece and Luxembourg were excluded from our analysis due to lack of data). Results, available upon request, remain qualitatively unaltered.
} 
has resulted in better consumption insurance, and further depletion of risk sharing opportunities.

(Table 4 goes about here)

Overall, we find that so far the introduction of the euro has neither caused an upward trend in output asymmetry, as predicted by the hypothesis that deeper financial integration would lead to higher industrial specialization and correspondingly higher output asymmetry, nor a downward trend, as predicted by the theory that more integration leads to more similarity. Our evidence suggests that such trends are quite slow to develop. It may well take decades before conclusive evidence can be reached. On an absolute level, however, and with few exceptions, the degree of asymmetry across countries appears to be small. Although the Eurozone may not be a true OCA, one common monetary policy appears not to create too much strain in the system. This view is reinforced by the evidence on consumption asymmetry. Consumption asymmetry is smaller than that of output, and actually has declined for both (log and CRRA) utility measures after the introduction of the euro. These findings suggest that consumption smoothing has progressed, probably due to better cross-country risk sharing possibilities. With deeper integration, consumption in the Eurozone is more cushioned against idiosyncratic output shocks and negative ECB monetary policy externalities.

\subsection{Enlarged $E \boldsymbol{U}$ and Candidate Countries}

In this section, we examine the patterns of output and consumption asymmetries when the current Eurozone group expands to the EU-15 (old members), EU-27 (enlarged EU) and EU-29 (enlarged EU and candidate countries). The main purpose of this section is to determine how close (or distant) non-Eurozone countries are to the Eurozone, and 
what challenges the ECB would face upon enlargement of the Eurozone in terms of setting one monetary policy.

First, we pay attention to output asymmetry patterns. Table 5 displays the results. For comparison purposes, in columns (3) we report the output-based asymmetry estimates for the Eurozone using log utility. ${ }^{17}$ Our first expansion of the Eurozone includes the remaining three long-standing EU members, Denmark, Sweden and U.K., which have so far maintained their own national currencies. Asymmetry measures calculated with the log-utility are reported in column (7). The inclusion of these three non-euro members has virtually no impact on the asymmetry estimates of the Eurozone members or on the asymmetry ranking. Ireland, Greece and Luxembourg continue to have the highest degree of asymmetry while France, Austria and Germany the lowest.

However, three more things are worth noting: First, compared to Sweden and U.K., Denmark seems to be the most asymmetric in output fluctuations and, therefore, stands to gain the most from risk sharing. Second, the U.K. has one of the smallest asymmetry estimates in the EU-15, which, in turn, translates into small potential welfare gains from the risk sharing arrangement. Lastly, the EU-15 group exhibits smaller output asymmetry than that of the Eurozone. Overall, our evidence suggests that the costs of joining the Eurozone for these three countries would be limited. It also downplays the alleged UK idiosyncrasy (e.g. Barrios et al., 2001), and policy recommendations arguing for non-EMU membership.

Next, we examine the enlarged union, the EU-27. The asymmetry estimates based on the log-utility are displayed in column (11). In general, output asymmetry estimates

\footnotetext{
${ }^{17}$ As before, we focus on the asymmetry measures calculated with the log utility in the discussion of Tables 5 and 6. We report the CRRA results for comparative purposes. Overall, only marginal differences arise between the two measures.
} 
are larger for the new EU members compared to those of the EU-15. Heterogeneity in this group is considerable, though. Bulgaria displays the highest degree of asymmetry. Malta, Romania and Estonia follow with asymmetry measures close to those of the Eurozone members, Ireland, Greece, and Luxembourg. Interestingly, for a considerable group of new member countries, the degree of asymmetry is comparable to the average in the EU-15. For instance, Slovenia, Cyprus and Hungary are already closely integrated with the EU-15, with the Czech Republic, Slovakia, Poland and Latvia and Lithuania being approximately at the average of EU-15 asymmetry. This should not come as a surprise since these countries are close geographically to the EU-15, and have opened up to the old EU much earlier than the rest. Based on our evidence, the latter group of countries is not more different from the Eurozone average in terms of output shocks than the typical Eurozone country itself. Therefore, giving up their own currency and adopting the euro instead, it would not lead to big economic costs. Neither would it make ECB monetary policy much more difficult. Clearly, that is different for Bulgaria and Romania, for instance.

Finally, we further extent the enlarged EU-27 to EU-29 to include two candidate countries, Croatia and Turkey. Column (15) contains the results. Not surprisingly, the results show that these countries are even more different from the Eurozone members than for instance Romania and Bulgaria. On the one hand, due to their significantly different output pattern, they stand to gain the most in the union from risk sharing. On the other hand, their inclusion to the Eurozone would make them vulnerable to a common monetary policy that would be almost suboptimal from a domestic perspective.

Note that the asymmetry measures for the Eurozone (and EU-15) countries are quite insensitive to the inclusion of the new member states and the two candidate 
countries. The direct effect of any enlargement wave on the total potential welfare gains of the old members appears to be virtually zero. The increase in overall output asymmetry in the enlarged EU, and any potential EU enlargement, creates some tension in the monetary union and monetary policy making in particular, and indirect negative effects may emerge. However, the final outcome largely depends on the degree to which country's consumption is hedged against idiosyncratic output shocks. For an assessment, we now turn to the asymmetry of consumption patterns in an enlarged EU.

(Table 5 goes about here)

Table 6 reports estimates of consumption-based asymmetry measures. Column (3) is the benchmark column, displaying the asymmetry measure calculated with the logutility for the Eurozone countries. In addition, column (7) shows the results for the EU15, column (11) for the EU-27 and column (15) for the EU-29. Comparing consumption asymmetries between the Eurozone and the three non-euro members of the EU-15, a similar picture, as for the case of output asymmetries, emerges. The inclusion of the three non-euro members leads a reduction of the average consumption-based asymmetry index. Overall, for the EU-15 as well as for the Eurozone, consumption asymmetry is, on average, considerably smaller than output asymmetry. In conclusion, expansion of the Eurozone to include Denmark, Sweden and the U.K., i.e., to all EU-15 members, is not likely to raise additional problems in the Eurozone. Not only are production structures quite similar apparently, but also consumption risk sharing is at a high level.

Including the new EU members (EU-27, column 11) and subsequently also the two candidate countries (EU-29, column 15) leaves the consumption asymmetry estimates of the old EU members practically unchanged. Without exception, the new members display a high degree of consumption asymmetry compared to the old EU 
members. The least asymmetric new member states have roughly the same asymmetry level as the most asymmetric old EU countries. This is completely different pattern, compared to output asymmetry evidence, where a substantial amount of new member states exhibit asymmetry around or below the EU-15 average. Apparently, consumption risk sharing is much less advanced in the new EU member states than in the old. Partly, this could be due to the less developed financial systems. Other possible explanations involve the presence of idiosyncratic (taste) shocks and other factors, such as the transition from planned to market economics of the central and east European memberstates. The study of Demyanyk and Volosovych (2007) also reports similar findings.

Such findings raise concerns, for some of these countries, about joining the soon the Eurozone. Despite their low output asymmetry, the costs of losing their own currency to the euro would not be limited. With lack of sufficient consumption risk sharing, suboptimal monetary policy from a domestic perspective might result in higher welfare costs than for the old EU countries with the same degree of output asymmetry. Nevertheless, there is that much is to be gained for these countries in terms of output and consumption risk sharing without apparent negative externalities for the current Eurozone members.

(Table 6 goes about here)

\section{Conclusion}

In this paper, we empirically investigate the patterns of output and consumption asymmetry in the Eurozone and the enlarged EU over the period 1992.Q1-2007.Q1. Our attempt serves primarily two purposes: First, we assess the impact of further and deeper integration with the introduction of the euro in 1999 on output and consumption 
asymmetry patterns for the Eurozone (EU-12) members. Second, we investigate to what extent the non-Eurozone EU member and candidate countries, clustered in various country groupings, i.e., EU-15, EU-27 and EU-29, differ from the Eurozone. This may have consequences for the ECB monetary policy making.

We follow Kalemli-Ozcan et al. (2001) and utilize the potential welfare gain from risk sharing among countries as the preferred measure of output and consumption asymmetry. Since we use quarterly data over a relatively short time span a caveat applies with respect to the robustness of our results and their interpretation.

The results show that the effects of the introduction of the euro on output asymmetry in the Eurozone are small yet. Although average output variability slightly decreases after 1999, output asymmetry remains, on average, about constant. This suggests that deeper financial integration due to the euro has not yet led to significant industrial specialization patterns and increased output asymmetry. Neither have increased trade and higher economic policy similarities resulted in increased symmetry.

Overall, the evidence suggests that such trends - if present - will take some time to be clearly visible in the data. In absolute terms, output asymmetry in the Eurozone appears to below, suggesting that one ECB monetary policy did not cause tensions in the system. This positive evidence on the role of the ECB is further reinforced by the findings on consumption asymmetry. Our results demonstrate that deeper economic and monetary integration significantly enhances consumption smoothing by reducing consumption growth dispersion for the Eurozone members. The introduction of the euro has led to further consumption risk sharing in the group and buffers consumption against idiosyncratic shocks to output. 
Turning to the non-Eurozone members, we find no significant difference in consumption and output asymmetries between the Eurozone and Denmark, Sweden and the UK. This suggests that the cost for these countries to give up their own currencies and join the Eurozone would be limited, as well as, the burden for the ECB to accommodate three more members by setting a common monetary policy.

However, for the new member states of the enlarged EU and the two candidate countries, different conclusions hold. First, heterogeneity among them is quite high. Some of the more integrated new member states exhibit output asymmetries that are no different than the average EU-15 member state, while for others the difference in asymmetry is vast. Second, consumption asymmetries for these countries are typically larger than output asymmetries. This is probably due to less developed financial markets to facilitate risk sharing as well as to taste shocks and the transition from plan to market economies in the 1990s for many of these countries.

All these reasons above could potentially create some strain in a monetary union. Given the heterogeneity in the enlarged EU, each country should be evaluated on the basis of its own characteristics. New member countries with relatively low output asymmetry may also face considerable welfare costs when facing a common EMU monetary policy due to high consumption asymmetry. Nevertheless, these countries can potentially realize high gains from output and consumption risk sharing in an enlarged EU, with little consequences for the risk sharing of old EU members.

Overall, while our results suggest that output dynamics (and, therefore, change in output asymmetry) may be slow to evolve, the potential to increase consumption risk sharing and reduce consumption asymmetry appears easier and faster to realize. Further integration of European capital (and credit) markets and better consumption risk sharing 
among EU countries could provide greater insurance against idiosyncratic shocks and pave the road for the EMU, without burdening either the prospective country with high welfare costs or the ECB with the difficult task of setting a common monetary policy in a highly asymmetric monetary union. 


\section{References}

Asdrubali P, Sorensen BE, Yosha O. Channels of Inter-sate Risk Sharing: United States 1963-90. Quarterly Journal of Economics 1996; 111; 1081-1110.

Barrios S, lhart MB, Elliott RJR, Sensier, M. Tale of Two Cycles: Co-Fluctuations Between UK Regions and the Euro Zone. The Manchester School 2003; 71(3); 265-292.

Baxter M, Crucini M. Business Cycles and the Asset Structure of Foreign Trade. International Economic Review 1995; 36; 821-854.

Bayoumi T, Eichengreen B 1993. Shocking Aspects of European Monetary Integration. In: Torres F, Giavazzi, F (Eds), Adjustment and Growth in the European Monetary Union. Cambridge University Press; 1993. p. 193-229.

Clark T, Shin K 2000. The Sources of Fluctuations Within and Across Countries. In: Hess G, van Wincoop E (Eds), International Macroeconomics. Cambridge University Press: New York; 2000. p. 189-217.

Clark TE, van Wincoop E. Borders and Business Cycles. Journal of International Economics 2001; 55; 59-85.

Coe D, Helpman E. International R\&D Spillovers. European Economic Review 1995; 39; $859-887$. 
Costello DM. A Cross-country, Cross-industry Comparison of Productivity Growth. Journal of Political Economy 1993; 101; 207-222.

De Grauwe P. The Economics of Monetary Integration. Oxford University Press: Oxford; 1992.

De Grauwe P, Vanhaverbeke W 1993. Is Europe an Optimum Currency Area?: Evidence from Regional Data. In: Masson PR, Taylor MP (Eds), Policy Issues in the Operation of Currency Unions. Cambridge University Press; 1993.

Demyanyk Y, Volosovych V. Gains from Financial Integration in the European Union: Evidence for New and Old Members. Federal Reserve Bank of St. Louis, Supervisory Policy Analysis Working Papers 2007; No. 2007-01.

Drummen M, Zimmermann H. The Structure of European Stock Returns. Financial Analysts Journal 1992; No. July-August, 15-26.

Fatas A. EMU: Countries or Regions? Lessons from the EMS Experience. European Economic Review 1997; 41; 743-751.

Forni M, Reichlin L. Federal Policies and Local Economies: Europe and the US. European Economic Review 2001; 45; 109-134. 
Frankel JA, Rose AK. The Endogeneity of the Optimum Currency Area Criteria. Economic Journal 1998; 108; 1009-1025.

Helg R, Manasse P, Monacelli T, Rovelli R. How Much (A)symmetry in Europe? Evidence from Industrial Sectors. European Economic Review 1995; 39(5); 1017-1041.

Heston S, Rouwenhorst, KG. Does Industrial Structure Explain the Benefits of International Diversification? Journal of Financial Economics 1994; 36; 3-27.

Kalemli-Ozcan S, Sorensen BE, Yosha O. Economic Integration, Industrial Specialization, and the Asymmetry of Macroeconomic Fluctuations. Journal of International Economics 2001; 55(1); 107-137.

Kalemli-Ozcan S, Sorensen BE, Yosha O. Risk Sharing and Industrial Specialization: Regional and International Evidence. American Economic Review 2003; 93(3); 903-918.

Kalemli-Ozcan S, Sorensen BE, Yosha O 2005. Asymmetric Shocks and Risk Sharing in a Monetary Union: Updated Evidence and Policy Implications for Europe. In: Huizinga H, Jonung L (Eds), The Internationalization of Asset Ownership in Europe. Cambridge University Press: New York; 2005.

Kenen PB 1969. The Theory of Optimum Currency Areas: An Eclectic View. In: Mundell R, Swoboda AK (Eds), Monetary Problems of the International Economy. University of Chicago Press: Chicago; 1969. p. 41-60. 
Krugman P 1993. Lessons of Massachusetts for EMU. In: Torres F, Giavazzi F. (Eds), Adjustment and Growth in the European Monetary Union. Cambridge University Press; 1993. p. 241-261.

Mundell R. A Theory of Optimum Currency Areas. American Economic Review 1961; $51 ; 657-665$.

Norrbin SC, Schlagenhauf DE. The Role of International Factors in the Business Cycle: A Multi-Country Study. Journal of International Economics 1996; 40(1-2); 85-104.

Obstfeld M. Evaluating Risky Consumption Paths: The Role of Intertemporal Substitutability. European Economic Review 1994; 38; 1471-1486.

Obstfeld M, Rogoff K. Foundations of International Macroeconomics. MIT Press: Cambridge; 1996.

Prasad E, Rogoff K, Wei SJ, Kose A. Effects of Financial Globalization on Developing Countries: Some Empirical Evidence. IMF Occasional Paper 2003; No. 220.

Sorensen B, Yosha O. International risk Sharing and European Monetary Unification. Journal of International Economics 1998; 45; 211-238.

Stockman AC. Sectoral and National Aggregate Disturbances to Industrial Output in Seven European Countries. Journal of Monetary Economics 1988; 21; 387-409. 
Stockman AC, Tesar L. Tastes and Technology in a Two-Country Model of the Business Cycle: Explaining International Comovements. American Economic Review 1995; 85; $168-185$.

Wincoop E van. Welfare Gains from International Risk Sharing. Journal of Monetary Economics 1994; 34; 175-200.

Wynne M, Koo J. Business Cycles under Monetary Union: A Comparison of the EU and US. Economica 2000; 67; 347-374. 
Table 1. Summary Statistics: GDP and final consumption per capita growth (Eurozone, 1992.Q1-1998.Q4 and 1999.Q1-2007.Q1)

\begin{tabular}{|c|c|c|c|c|c|}
\hline \multirow{2}{*}{ Countries } & \multicolumn{2}{|c|}{ GDP } & \multicolumn{2}{|c|}{ Consumption } & \multirow{2}{*}{$\begin{array}{l}\text { Relative } \\
\text { Volatility }\end{array}$} \\
\hline & mean & st. dev. & mean & st. dev. & \\
\hline \multicolumn{6}{|l|}{ 1992.01-1998.04 } \\
\hline Austria & 0.487 & 0.390 & 0.347 & 0.323 & 0.829 \\
\hline Belgium & 0.427 & 0.751 & 0.333 & 0.412 & 0.548 \\
\hline Finland & 0.703 & 0.899 & 0.324 & 0.793 & 0.882 \\
\hline France & 0.317 & 0.454 & 0.244 & 0.486 & 1.069 \\
\hline Germany & 0.245 & 0.694 & 0.352 & 0.844 & 1.217 \\
\hline Greece & 0.296 & 1.791 & 0.334 & 1.080 & 0.603 \\
\hline Ireland & 2.614 & 1.618 & 2.003 & 0.989 & 0.611 \\
\hline Italy & 0.283 & 0.560 & 0.196 & 0.665 & 1.189 \\
\hline Luxembourg & 1.240 & 1.788 & 0.290 & 1.233 & 0.689 \\
\hline Netherlands & 0.614 & 0.619 & 0.537 & 0.655 & 1.057 \\
\hline Portugal & 1.014 & 0.438 & 0.922 & 0.567 & 1.295 \\
\hline Spain & 0.564 & 0.875 & 0.485 & 0.826 & 0.944 \\
\hline Eurozone & 0.734 & 0.906 & 0.531 & 0.739 & 0.911 \\
\hline \multicolumn{6}{|l|}{ 1999.01-2007.01 } \\
\hline Austria & 0.395 & 0.366 & 0.280 & 0.303 & 0.827 \\
\hline Belgium & 0.433 & 0.505 & 0.341 & 0.403 & 0.798 \\
\hline Finland & 0.788 & 0.766 & 0.632 & 0.306 & 0.399 \\
\hline France & 0.419 & 0.405 & 0.456 & 0.259 & 0.639 \\
\hline Germany & 0.373 & 0.518 & 0.132 & 0.551 & 1.063 \\
\hline Greece & 1.061 & 1.430 & 0.873 & 1.178 & 0.824 \\
\hline Ireland & 1.254 & 1.871 & 1.095 & 1.062 & 0.568 \\
\hline Italy & 0.253 & 0.502 & 0.201 & 0.377 & 0.750 \\
\hline Luxembourg & 0.862 & 1.459 & 0.681 & 1.018 & 0.698 \\
\hline Netherlands & 0.402 & 0.478 & 0.337 & 0.408 & 0.855 \\
\hline Portugal & 0.243 & 0.721 & 0.327 & 0.543 & 0.754 \\
\hline Spain & 0.595 & 0.440 & 0.658 & 0.537 & 1.221 \\
\hline Eurozone & 0.590 & 0.788 & 0.501 & 0.579 & 0.783 \\
\hline
\end{tabular}

$\left({ }^{*}\right)$ Relative Volatility is the ratio of the standard deviation of total consumption per capita growth to that of GDP per capita growth. All numbers are multiplied by 100, except for Relative Volatility. Line Eurozone reports statistics for the 12 euro-area member states. 
Table 2. Summary Statistics: GDP and final consumption per capita growth (EU and candidate countries, 1992.Q1-2007.Q1)

\begin{tabular}{lccccc}
\hline \multicolumn{1}{c}{ Countries } & \multicolumn{2}{c}{ GDP } & \multicolumn{2}{c}{ Consumption } & Relative \\
& mean & st. dev. & mean & st. dev. & Volatility* \\
\hline \hline Austria & 0.438 & 0.377 & 0.311 & 0.312 & 0.827 \\
Belgium & 0.430 & 0.626 & 0.337 & 0.403 & 0.644 \\
Finland & 0.748 & 0.825 & 0.489 & 0.601 & 0.729 \\
France & 0.371 & 0.428 & 0.357 & 0.393 & 0.919 \\
Germany & 0.313 & 0.605 & 0.235 & 0.706 & 1.167 \\
Greece & 0.704 & 1.640 & 0.622 & 1.156 & 0.705 \\
Ireland & 1.889 & 1.873 & 1.519 & 1.117 & 0.597 \\
Italy & 0.267 & 0.526 & 0.198 & 0.526 & 1.002 \\
Luxembourg & 1.038 & 1.618 & 0.498 & 1.131 & 0.699 \\
Netherlands & 0.501 & 0.554 & 0.430 & 0.542 & 0.978 \\
Portugal & 0.603 & 0.715 & 0.604 & 0.626 & 0.875 \\
Spain & 0.581 & 0.673 & 0.577 & 0.687 & 1.021 \\
Eurozone & $\mathbf{0 . 6 5 7}$ & $\mathbf{0 . 8 7 2}$ & $\mathbf{0 . 5 1 5}$ & $\mathbf{0 . 6 8 3}$ & $\mathbf{0 . 8 4 7}$ \\
Denmark & 0.492 & 0.816 & 0.417 & 0.768 & 0.942 \\
Sweden & 0.691 & 0.418 & 0.313 & 0.339 & 0.810 \\
UK & 0.616 & 0.306 & 0.621 & 0.405 & 1.324 \\
EU-15 & $\mathbf{0 . 6 4 5}$ & $\mathbf{0 . 8 0 0}$ & $\mathbf{0 . 5 0 2}$ & $\mathbf{0 . 6 4 7}$ & $\mathbf{0 . 8 8 3}$ \\
Bulgaria & 0.681 & 2.927 & 0.585 & 3.822 & 1.306 \\
Cyprus & 0.471 & 0.667 & 0.685 & 1.457 & 2.187 \\
Czech Republic & 0.898 & 1.030 & 0.759 & 0.865 & 0.840 \\
Estonia & 1.748 & 1.803 & 1.789 & 2.235 & 1.240 \\
Hungary & 0.853 & 0.502 & 0.760 & 1.135 & 2.260 \\
Latvia & 2.045 & 0.901 & 1.871 & 1.484 & 1.646 \\
Lithuania & 1.724 & 1.021 & 1.721 & 0.989 & 0.969 \\
Malta & 0.235 & 1.829 & 0.320 & 1.757 & 0.961 \\
Poland & 1.263 & 1.119 & 1.205 & 0.903 & 0.807 \\
Romania & 1.463 & 1.799 & 1.923 & 1.889 & 1.050 \\
Slovakia & 1.275 & 0.935 & 1.038 & 1.833 & 1.961 \\
Slovenia & 1.110 & 0.704 & 0.827 & 1.062 & 1.507 \\
EU-27 & $\mathbf{0 . 8 6 8}$ & $\mathbf{1 . 0 0 9}$ & $\mathbf{0 . 7 7 8}$ & $\mathbf{1 . 0 7 9}$ & $\mathbf{1 . 1 1 0}$ \\
Croatia & 1.241 & 2.539 & 0.917 & 2.582 & 1.017 \\
Turkey & 0.992 & 3.766 & 0.740 & 3.204 & 0.851 \\
EU-29 & $\mathbf{0 . 8 8 6}$ & $\mathbf{1 . 1 5 7}$ & $\mathbf{0 . 7 8 2}$ & $\mathbf{1 . 2 0 4}$ & $\mathbf{1 . 0 9 8}$ \\
\hline
\end{tabular}

$\left(^{*}\right)$ Relative Volatility is the ratio of the standard deviation of total consumption per capita growth to that of GDP per capita growth. All numbers are multiplied by 100, except for Relative Volatility. Lines Eurozone, EU-15, EU-27 and $E U-29$ report statistics for $12,15,27$ and 29 countries, respectively. 
Table 3. Fluctuations Asymmetry of GDP (Eurozone)

\begin{tabular}{|c|c|c|c|c|}
\hline Countries & $\begin{array}{c}(1) \\
\text { Variance }\end{array}$ & $\begin{array}{c}\text { (2) } \\
\text { Covariance }\end{array}$ & $\begin{array}{c}\text { (3) } \\
G^{G D P}\end{array}$ & $\begin{array}{c}\text { (4) } \\
C R R A^{G D P}\end{array}$ \\
\hline \multicolumn{5}{|c|}{ 1992.Q1-2007.Q1 } \\
\hline Austria & 0.141 & 0.098 & 0.028 & 0.003 \\
\hline Belgium & 0.391 & 0.163 & 0.058 & 0.015 \\
\hline Finland & 0.672 & 0.192 & 0.113 & 0.047 \\
\hline France & 0.182 & 0.128 & 0.023 & 0.003 \\
\hline Germany & 0.364 & 0.208 & 0.029 & 0.009 \\
\hline Greece & 2.664 & 0.140 & 0.638 & 0.828 \\
\hline Ireland & 3.387 & 0.091 & 0.843 & 1.342 \\
\hline Italy & 0.275 & 0.147 & 0.037 & 0.007 \\
\hline Luxembourg & 2.601 & 0.136 & 0.624 & 0.790 \\
\hline Netherlands & 0.304 & 0.156 & 0.040 & 0.008 \\
\hline Portugal & 0.507 & 0.036 & 0.150 & 0.033 \\
\hline Spain & 0.445 & 0.170 & 0.068 & 0.020 \\
\hline Eurozone & 0.994 & 0.139 & 0.221 & 0.259 \\
\hline \multicolumn{5}{|c|}{ 1992.Q1-1998.Q4 } \\
\hline Austria & 0.149 & 0.118 & 0.031 & 0.005 \\
\hline Belgium & 0.550 & 0.231 & 0.075 & 0.030 \\
\hline Finland & 0.828 & 0.271 & 0.124 & 0.072 \\
\hline France & 0.210 & 0.154 & 0.028 & 0.005 \\
\hline Germany & 0.475 & 0.259 & 0.042 & 0.017 \\
\hline Greece & 3.007 & 0.283 & 0.663 & 1.100 \\
\hline Ireland & 1.846 & -0.061 & 0.545 & 0.425 \\
\hline Italy & 0.320 & 0.147 & 0.059 & 0.013 \\
\hline Luxembourg & 3.257 & 0.070 & 0.832 & 1.313 \\
\hline Netherlands & 0.358 & 0.179 & 0.052 & 0.013 \\
\hline Portugal & 0.192 & 0.011 & 0.095 & 0.010 \\
\hline Spain & 0.782 & 0.273 & 0.112 & 0.062 \\
\hline Eurozone & 0.998 & 0.161 & 0.221 & 0.255 \\
\hline \multicolumn{5}{|c|}{ 1999.01-2007.01 } \\
\hline Austria & 0.138 & 0.083 & 0.026 & 0.003 \\
\hline Belgium & 0.271 & 0.105 & 0.049 & 0.008 \\
\hline Finland & 0.564 & 0.126 & 0.112 & 0.034 \\
\hline France & 0.159 & 0.103 & 0.022 & 0.002 \\
\hline Germany & 0.270 & 0.161 & 0.020 & 0.004 \\
\hline Greece & 2.329 & 0.008 & 0.612 & 0.610 \\
\hline Ireland & 4.276 & 0.243 & 0.981 & 2.038 \\
\hline Italy & 0.246 & 0.147 & 0.022 & 0.004 \\
\hline Luxembourg & 2.112 & 0.198 & 0.463 & 0.493 \\
\hline Netherlands & 0.261 & 0.141 & 0.028 & 0.005 \\
\hline Portugal & 0.509 & 0.078 & 0.122 & 0.030 \\
\hline Spain & 0.185 & 0.086 & 0.037 & 0.004 \\
\hline Eurozone & 0.943 & 0.123 & 0.208 & 0.270 \\
\hline
\end{tabular}

$G D P_{i}$ is real gross domestic product per capita of each country and $G D P_{T}$ aggregate real gross domestic product per capita of the 12 euro-area countries.

$\operatorname{Var}$ is $10^{4} * \sigma_{i}^{2}$, where $\sigma_{i}^{2}=\operatorname{var}\left(\Delta \log G D P_{i}\right)$ [in other words, it is $\operatorname{var}\left(100^{*} \Delta \log \mathrm{GDP}\right)$ ].

$\operatorname{Cov}$ is $10^{4} \operatorname{cov}_{i}$, where $\operatorname{cov}_{i}=\operatorname{cov}\left(\Delta \log G D P_{i}, \Delta \log G D P_{T}\right)$.

$G^{G D P}$ is $10^{2 * 1} / \delta\left(1 / 2 \sigma^{2}+1 / 2 \sigma_{i}^{2}-\operatorname{cov}_{i}\right)$, where $\delta=0.005$ (discount rate).

$C R R A^{G D P}$ is $10^{2} *\left[\log \left(\delta-(1-\gamma) \mu-{ }^{1} / 2(1-\gamma)^{2} \sigma^{2}\right)-\log \left(\delta-\left(\mu-\gamma \mu{ }^{1} / 2 \sigma_{i}^{2}+{ }^{1} / 2 \gamma^{2} \sigma^{2}-\gamma \operatorname{cov}_{i}\right)\right)+{ }^{1} / 1-\gamma \log \left(\delta-(1-\gamma) \mu-1 / 2(1-\gamma)^{2} \sigma_{i}{ }^{2}\right)-{ }^{1} / 1-\gamma \log \left(\delta-(1-\gamma) \mu-{ }^{1} / 2(1-\gamma)^{2} \sigma^{2}\right)\right]$, where the risk aversion parameter is $\gamma=3$ and growth rate of the group-wide GDP, GDPT, is $\mu=0.004$. 
Table 4. Fluctuations Asymmetry of Consumption (Eurozone)

\begin{tabular}{|c|c|c|c|c|}
\hline Countries & $\begin{array}{c}(1) \\
\text { Variance }\end{array}$ & $\begin{array}{c}\text { (2) } \\
\text { Covariance }\end{array}$ & $\begin{array}{c}\text { (3) } \\
G^{C O N}\end{array}$ & $\begin{array}{c}\text { (4) } \\
C R R A^{C O N}\end{array}$ \\
\hline \multicolumn{5}{|c|}{ 1992.Q1-2007.Q1 } \\
\hline Austria & 0.097 & 0.036 & 0.036 & 0.003 \\
\hline Belgium & 0.162 & 0.051 & 0.044 & 0.005 \\
\hline Finland & 0.362 & 0.074 & 0.083 & 0.017 \\
\hline France & 0.154 & 0.069 & 0.033 & 0.004 \\
\hline Germany & 0.496 & 0.195 & 0.056 & 0.024 \\
\hline Greece & 1.323 & 0.028 & 0.346 & 0.229 \\
\hline Ireland & 1.212 & 0.059 & 0.303 & 0.191 \\
\hline Italy & 0.276 & 0.098 & 0.049 & 0.009 \\
\hline Luxembourg & 1.271 & 0.084 & 0.305 & 0.210 \\
\hline Netherlands & 0.293 & 0.099 & 0.053 & 0.010 \\
\hline Portugal & 0.388 & 0.028 & 0.112 & 0.021 \\
\hline Spain & 0.466 & 0.072 & 0.110 & 0.029 \\
\hline Eurozone & 0.542 & 0.074 & 0.128 & 0.063 \\
\hline \multicolumn{5}{|c|}{ 1992.01-1998.O4 } \\
\hline Austria & 0.108 & 0.040 & 0.051 & 0.005 \\
\hline Belgium & 0.174 & 0.059 & 0.058 & 0.007 \\
\hline Finland & 0.655 & 0.183 & 0.116 & 0.051 \\
\hline France & 0.244 & 0.106 & 0.052 & 0.009 \\
\hline Germany & 0.690 & 0.273 & 0.080 & 0.046 \\
\hline Greece & 0.909 & 0.090 & 0.226 & 0.109 \\
\hline Ireland & 0.985 & -0.059 & 0.320 & 0.129 \\
\hline Italy & 0.457 & 0.163 & 0.077 & 0.024 \\
\hline Luxembourg & 1.484 & 0.176 & 0.327 & 0.281 \\
\hline Netherlands & 0.435 & 0.151 & 0.077 & 0.023 \\
\hline Portugal & 0.317 & 0.026 & 0.110 & 0.017 \\
\hline Spain & 0.699 & 0.095 & 0.171 & 0.065 \\
\hline Eurozone & 0.596 & 0.109 & 0.139 & 0.064 \\
\hline \multicolumn{5}{|c|}{ 1999.01-2007.01 } \\
\hline Austria & 0.089 & 0.032 & 0.025 & 0.001 \\
\hline Belgium & 0.156 & 0.044 & 0.036 & 0.003 \\
\hline Finland & 0.090 & -0.016 & 0.049 & 0.002 \\
\hline France & 0.065 & 0.039 & 0.015 & 0.001 \\
\hline Germany & 0.345 & 0.131 & 0.039 & 0.012 \\
\hline Greece & 1.648 & -0.023 & 0.442 & 0.354 \\
\hline Ireland & 1.093 & 0.154 & 0.215 & 0.150 \\
\hline Italy & 0.138 & 0.046 & 0.030 & 0.003 \\
\hline Luxembourg & 1.030 & 0.009 & 0.272 & 0.139 \\
\hline Netherlands & 0.174 & 0.056 & 0.034 & 0.004 \\
\hline Portugal & 0.325 & 0.029 & 0.086 & 0.014 \\
\hline Spain & 0.280 & 0.053 & 0.062 & 0.010 \\
\hline Eurozone & 0.453 & 0.046 & 0.109 & 0.058 \\
\hline
\end{tabular}

$C_{i}$ is real final consumption expenditure per capita of each country and $C_{T}$ group-wide final consumption expenditure per capita of the 12 euro-area countries.

Var is $10^{4} * \sigma_{i}^{2}$, where $\sigma_{i}^{2}=\operatorname{var}\left(\Delta \log C_{i}\right)$ [in other words, it is $\left.\operatorname{var}(100 * \Delta \log C)\right]$.

$\operatorname{Cov}$ is $10^{4} * \operatorname{cov}_{i}$, where $\operatorname{cov}_{i}=\operatorname{cov}\left(\Delta \log C_{i}, \Delta \log C_{T}\right)$.

$G^{C O N}$ is $10^{2 * 1} / \delta\left(1 / 2 \sigma^{2}+1 / 2 \sigma_{i}^{2}-\operatorname{cov}_{i}\right)$, where $\delta=0.005$ (discount rate).

$C R R A^{C O N}$ is $10^{2 *}\left[\log \left(\delta-(1-\gamma) \mu-{ }^{1} / 2(1-\gamma)^{2} \sigma^{2}\right)-\log \left(\delta-\left(\mu-\gamma \mu+{ }^{1} / 2 \sigma_{i}{ }^{2}+{ }^{1} / 2 \gamma^{2} \sigma^{2}-\gamma \operatorname{cov} i\right)\right)+{ }^{1} / 1-\gamma \log \left(\delta-(1-\gamma) \mu-{ }^{1} / 2(1-\gamma)^{2} \sigma_{i}^{2}\right)-{ }^{1} / 1-\gamma \log \left(\delta-(1-\gamma) \mu-{ }^{1} / 2(1-\gamma)^{2} \sigma^{2}\right)\right]$, where the risk aversion parameter is $\gamma=3$ and the growth rate of group-wide consumption, $C_{T}$, is $\mu=0.003$. 
Table 5. Fluctuations Asymmetry of GDP (EU and candidate countries, 1992.Q1-2007.Q1)

\begin{tabular}{|c|c|c|c|c|c|c|c|c|c|c|c|c|c|c|c|c|}
\hline & (1) & (2) & $\begin{array}{l}\text { (3) } \\
G^{G D P}\end{array}$ & $\begin{array}{c}(4) \\
C R R A^{G D P}\end{array}$ & (5) & (6) & $\begin{array}{l}\text { (7) } \\
G_{G D P}\end{array}$ & $\begin{array}{c}(8) \\
C R R A^{G D P}\end{array}$ & (9) & (10) & $\begin{array}{l}(11) \\
G D P\end{array}$ & $\begin{array}{c}(12) \\
C R A^{G D P}\end{array}$ & (13) & (14) & $\begin{array}{l}(15) \\
G D P\end{array}$ & $\begin{array}{c}(16) \\
C R R 4^{G D P}\end{array}$ \\
\hline & Var & $\mathrm{Cov}$ & $G^{G D P}$ & & & $\mathrm{Cov}$ & $G^{G D P}$ & & & & $G^{G D P}$ & & Var & & $G^{G D P}$ & \\
\hline Countries & \multicolumn{4}{|c|}{ EU-12 } & \multicolumn{4}{|c|}{ EU-15 } & \multicolumn{4}{|c|}{ EU-27 } & \multicolumn{4}{|c|}{ EU-29 } \\
\hline Austria & 0.141 & 0.098 & 0.028 & 0.003 & 0.141 & 0.088 & 0.025 & 0.003 & 0.141 & 0.086 & 0.025 & 0.002 & 0.141 & 0.086 & 0.026 & 0.002 \\
\hline Belgium & 0.391 & 0.163 & 0.058 & 0.015 & 0.391 & 0.146 & 0.059 & 0.014 & 0.391 & 0.142 & 0.059 & 0.013 & 0.391 & 0.143 & 0.060 & 0.014 \\
\hline Finland & 0.672 & 0.192 & 0.113 & 0.047 & 0.672 & 0.172 & 0.116 & 0.045 & 0.672 & 0.165 & 0.118 & 0.042 & 0.672 & 0.162 & 0.120 & 0.044 \\
\hline France & 0.182 & 0.128 & 0.023 & 0.003 & 0.182 & 0.117 & 0.021 & 0.003 & 0.182 & 0.114 & 0.021 & 0.002 & 0.182 & 0.113 & 0.023 & 0.003 \\
\hline Germany & 0.364 & 0.208 & 0.029 & 0.009 & 0.364 & 0.185 & 0.032 & 0.009 & 0.364 & 0.179 & 0.034 & 0.009 & 0.364 & 0.180 & 0.035 & 0.009 \\
\hline Greece & 2.664 & 0.140 & 0.638 & 0.828 & 2.664 & 0.126 & 0.637 & 0.780 & 2.664 & 0.120 & 0.638 & 0.720 & 2.664 & 0.120 & 0.640 & 0.740 \\
\hline Ireland & 3.387 & 0.091 & 0.843 & 1.342 & 3.387 & 0.091 & 0.835 & 1.263 & 3.387 & 0.089 & 0.834 & 1.165 & 3.387 & 0.101 & 0.830 & 1.198 \\
\hline Italy & 0.275 & 0.147 & 0.037 & 0.007 & 0.275 & 0.134 & 0.036 & 0.006 & 0.275 & 0.131 & 0.035 & 0.006 & 0.275 & 0.128 & 0.038 & 0.006 \\
\hline Luxembourg & 2.601 & 0.136 & 0.624 & 0.790 & 2.601 & 0.115 & 0.627 & 0.744 & 2.601 & 0.110 & 0.627 & 0.687 & 2.601 & 0.119 & 0.625 & 0.706 \\
\hline Netherlands & 0.304 & 0.156 & 0.040 & 0.008 & 0.304 & 0.141 & 0.040 & 0.008 & 0.304 & 0.136 & 0.040 & 0.007 & 0.304 & 0.133 & 0.043 & 0.008 \\
\hline Portugal & 0.507 & 0.036 & 0.150 & 0.033 & 0.507 & 0.036 & 0.143 & 0.030 & 0.507 & 0.035 & 0.141 & 0.028 & 0.507 & 0.031 & 0.145 & 0.029 \\
\hline Spain & 0.445 & 0.170 & 0.068 & 0.020 & 0.445 & 0.150 & 0.071 & 0.019 & 0.445 & 0.146 & 0.070 & 0.017 & 0.445 & 0.146 & 0.072 & 0.018 \\
\hline $\begin{array}{l}\text { Eurozone } \\
\text { (mean) }\end{array}$ & 0.994 & 0.139 & 0.221 & 0.259 & 0.994 & 0.125 & 0.220 & 0.244 & 0.994 & 0.121 & 0.220 & 0.225 & 0.994 & 0.122 & 0.221 & 0.231 \\
\hline Denmark & & & & & 0.658 & 0.140 & 0.128 & 0.045 & 0.658 & 0.137 & 0.128 & 0.042 & 0.658 & 0.135 & 0.130 & 0.043 \\
\hline Sweden & & & & & 0.172 & 0.056 & 0.049 & 0.005 & 0.172 & 0.055 & 0.048 & 0.004 & 0.172 & 0.052 & 0.051 & 0.004 \\
\hline UK & & & & & 0.092 & 0.067 & 0.024 & 0.002 & 0.092 & 0.064 & 0.023 & 0.002 & 0.092 & 0.063 & 0.025 & 0.002 \\
\hline $\begin{array}{l}E U-15 \\
\text { (mean) }\end{array}$ & & & & & 0.857 & 0.118 & 0.190 & 0.198 & 0.857 & 0.114 & 0.189 & 0.183 & 0.857 & 0.114 & 0.191 & 0.188 \\
\hline Bulgaria & & & & & & & & & 8.611 & 0.152 & 2.109 & 7.529 & 8.611 & 0.164 & 2.104 & 7.742 \\
\hline Cyprus & & & & & & & & & 0.439 & 0.047 & 0.118 & 0.021 & 0.439 & 0.046 & 0.120 & 0.022 \\
\hline Czech Republic & & & & & & & & & 1.042 & -0.001 & 0.293 & 0.112 & 1.042 & 0.012 & 0.288 & 0.115 \\
\hline Estonia & & & & & & & & & 3.135 & 0.126 & 0.753 & 0.997 & 3.135 & 0.157 & 0.739 & 1.024 \\
\hline Hungary & & & & & & & & & 0.248 & 0.039 & 0.075 & 0.008 & 0.248 & 0.041 & 0.075 & 0.008 \\
\hline Latvia & & & & & & & & & 0.782 & 0.012 & 0.221 & 0.064 & 0.782 & 0.025 & 0.217 & 0.066 \\
\hline Lithuania & & & & & & & & & 1.016 & -0.027 & 0.300 & 0.106 & 1.016 & -0.010 & 0.293 & 0.110 \\
\hline Malta & & & & & & & & & 3.272 & 0.011 & 0.845 & 1.089 & 3.272 & 0.020 & 0.842 & 1.120 \\
\hline Poland & & & & & & & & & 1.223 & 0.078 & 0.299 & 0.152 & 1.223 & 0.088 & 0.295 & 0.156 \\
\hline Romania & & & & & & & & & 3.151 & 0.001 & 0.819 & 1.010 & 3.151 & -0.008 & 0.826 & 1.039 \\
\hline Slovakia & & & & & & & & & 0.861 & -0.034 & 0.264 & 0.077 & 0.861 & -0.024 & 0.261 & 0.079 \\
\hline Slovenia & & & & & & & & & 0.485 & 0.012 & 0.147 & 0.026 & 0.485 & 0.027 & 0.141 & 0.026 \\
\hline $\begin{array}{l}E U-27 \\
\text { (mean) }\end{array}$ & & & & & & & & & 1.375 & 0.079 & 0.336 & 0.516 & 1.375 & 0.083 & 0.336 & 0.531 \\
\hline Croatia & & & & & & & & & & & & & 6.282 & 0.253 & 1.478 & 4.111 \\
\hline Turkey & & & & & & & & & & & & & $\begin{array}{c}13.38 \\
6\end{array}$ & 0.319 & 3.221 & 18.699 \\
\hline $\begin{array}{l}E U-29 \\
\text { (mean) }\end{array}$ & & & & & & & & & & & & & 1.958 & 0.097 & 0.475 & 1.281 \\
\hline
\end{tabular}

$G D P_{i}$ is real gross domestic product per capita of each country and $G D P_{T}$ group-wide real gross domestic product per capita.

$\operatorname{Var}$ is $10^{4} \sigma_{i}^{2}$, where $\sigma_{i}^{2}=\operatorname{var}\left(\Delta \log G D P_{i}\right)$ [in other words, it is $\left.\operatorname{var}(100 * \Delta \log G D P)\right]$. Cov is $10^{4} * \operatorname{cov}_{i}$, where $\operatorname{cov} v_{i}=\operatorname{cov}\left(\Delta \log G D P_{i}, \Delta \log G D P_{T}\right)$.

$G^{G D P}$ is $10^{2 * 1} / \delta\left(1 / 2 \sigma^{2}+1 / 2 \sigma_{i}^{2}-\operatorname{cov}_{i}\right)$, where $\delta=0.005$ (discount rate). $C R R A^{G D P}$ is $10^{2 *}\left[\log \left(\delta-(1-\gamma) \mu-1 / 2(1-\gamma)^{2} \sigma^{2}\right)-\log \left(\delta-\left(\mu-\gamma \mu+^{1} / 2 \sigma_{i}^{2}+{ }^{1} / 2 \gamma^{2} \sigma^{2}-\gamma \operatorname{cov} i\right)\right)+{ }^{1} / 1-\gamma / \log \left(\delta-(1-\gamma) \mu-{ }^{1} / 2(1-\gamma)^{2} \sigma_{i}^{2}\right)-{ }^{1} / 1-\gamma / \log \left(\delta-(1-\gamma) \mu-1 / 2(1-\gamma)^{2} \sigma^{2}\right)\right]$, where the risk aversion parameter is $\gamma=3$ and the growth rate of group-wide output, $G D P_{T}$, is $\mu=0.004$. 
Table 6. Fluctuations Asymmetry of Consumption (EU and candidate countries, 1992.Q1-2007.Q1)

\begin{tabular}{|c|c|c|c|c|c|c|c|c|c|c|c|c|c|c|c|c|}
\hline & $\begin{array}{l}\text { (1) } \\
\text { Var }\end{array}$ & $\begin{array}{l}\text { (2) } \\
\text { Cov }\end{array}$ & $\begin{array}{c}(3) \\
G^{C O N}\end{array}$ & $\begin{array}{c}\text { (4) } \\
\text { CRRA } A^{C O N}\end{array}$ & $\begin{array}{l}\text { (5) } \\
\text { Var }\end{array}$ & $\begin{array}{l}(6) \\
C o v\end{array}$ & $\begin{array}{c}\text { (7) } \\
G^{\text {CON }}\end{array}$ & $\begin{array}{c}(8) \\
\text { CRRA }^{C O N}\end{array}$ & $\begin{array}{l}\text { (9) } \\
\text { Var }\end{array}$ & $\begin{array}{l}\text { (10) } \\
\mathrm{Cov}\end{array}$ & $\begin{array}{c}(11) \\
G^{C O N}\end{array}$ & $\begin{array}{c}\text { (12) } \\
\text { CRRA }^{\text {CON }}\end{array}$ & $\begin{array}{l}\text { (13) } \\
\text { Var }\end{array}$ & $\begin{array}{l}\text { (14) } \\
\mathrm{Cov}\end{array}$ & $\begin{array}{l}\text { (15) } \\
G^{\text {CON }}\end{array}$ & $\begin{array}{c}(16) \\
\text { CRRA } A^{C O N}\end{array}$ \\
\hline Countries & \multicolumn{4}{|c|}{ EU-12 } & \multicolumn{4}{|c|}{ EU-15 } & \multicolumn{4}{|c|}{ EU-27 } & \multicolumn{4}{|c|}{ EU-29 } \\
\hline Austria & 0.097 & 0.036 & 0.036 & 0.003 & 0.097 & 0.034 & 0.031 & 0.002 & 0.097 & 0.031 & 0.030 & 0.002 & 0.097 & 0.030 & 0.030 & 0.002 \\
\hline Belgium & 0.162 & 0.051 & 0.044 & 0.005 & 0.162 & 0.043 & 0.042 & 0.004 & 0.162 & 0.041 & 0.041 & 0.003 & 0.162 & 0.044 & 0.039 & 0.003 \\
\hline Finland & 0.362 & 0.074 & 0.083 & 0.017 & 0.362 & 0.063 & 0.082 & 0.016 & 0.362 & 0.061 & 0.082 & 0.014 & 0.362 & 0.063 & 0.079 & 0.015 \\
\hline France & 0.154 & 0.069 & 0.033 & 0.004 & 0.154 & 0.064 & 0.030 & 0.003 & 0.154 & 0.060 & 0.030 & 0.003 & 0.154 & 0.059 & 0.029 & 0.003 \\
\hline Germany & 0.496 & 0.195 & 0.056 & 0.024 & 0.496 & 0.165 & 0.065 & 0.024 & 0.496 & 0.160 & 0.066 & 0.022 & 0.496 & 0.147 & 0.071 & 0.024 \\
\hline Greece & 1.323 & 0.028 & 0.346 & 0.229 & 1.323 & 0.014 & 0.347 & 0.212 & 1.323 & 0.010 & 0.347 & 0.194 & 1.323 & 0.010 & 0.346 & 0.201 \\
\hline Ireland & 1.212 & 0.059 & 0.303 & 0.191 & 1.212 & 0.054 & 0.299 & 0.178 & 1.212 & 0.051 & 0.299 & 0.162 & 1.212 & 0.044 & 0.301 & 0.169 \\
\hline Italy & 0.276 & 0.098 & 0.049 & 0.009 & 0.276 & 0.093 & 0.046 & 0.008 & 0.276 & 0.087 & 0.047 & 0.008 & 0.276 & 0.084 & 0.047 & 0.008 \\
\hline Luxembourg & 1.271 & 0.084 & 0.305 & 0.210 & 1.271 & 0.084 & 0.299 & 0.194 & 1.271 & 0.076 & 0.301 & 0.178 & 1.271 & 0.067 & 0.304 & 0.185 \\
\hline Netherlands & 0.293 & 0.099 & 0.053 & 0.010 & 0.293 & 0.088 & 0.053 & 0.010 & 0.293 & 0.084 & 0.053 & 0.009 & 0.293 & 0.077 & 0.055 & 0.009 \\
\hline Portugal & 0.388 & 0.028 & 0.112 & 0.021 & 0.388 & 0.028 & 0.106 & 0.019 & 0.388 & 0.026 & 0.105 & 0.017 & 0.388 & 0.018 & 0.108 & 0.018 \\
\hline Spain & 0.466 & 0.072 & 0.110 & 0.029 & 0.466 & 0.064 & 0.108 & 0.026 & 0.466 & 0.059 & 0.108 & 0.024 & 0.466 & 0.053 & 0.110 & 0.025 \\
\hline \multicolumn{17}{|l|}{ Eurozone } \\
\hline (mean) & 0.542 & 0.074 & 0.128 & 0.063 & 0.542 & 0.066 & 0.126 & 0.058 & 0.542 & 0.062 & 0.126 & 0.053 & 0.542 & 0.058 & 0.127 & 0.055 \\
\hline Denmark & & & & & 0.585 & 0.095 & 0.122 & 0.040 & 0.585 & 0.091 & 0.122 & 0.037 & 0.585 & 0.089 & 0.122 & 0.038 \\
\hline Sweden & & & & & 0.114 & 0.050 & 0.027 & 0.002 & 0.114 & 0.046 & 0.027 & 0.002 & 0.114 & 0.048 & 0.025 & 0.002 \\
\hline UK & & & & & 0.161 & 0.048 & 0.040 & 0.004 & 0.161 & 0.046 & 0.039 & 0.003 & 0.161 & 0.042 & 0.040 & 0.003 \\
\hline \multicolumn{17}{|l|}{$E U-15$} \\
\hline (mean) & & & & & 0.491 & 0.066 & 0.113 & 0.049 & 0.491 & 0.062 & 0.113 & 0.045 & 0.491 & 0.058 & 0.114 & 0.047 \\
\hline Bulgaria & & & & & & & & & 14.548 & 0.378 & 3.469 & 23.334 & 14.548 & 0.394 & 3.460 & 24.214 \\
\hline Cyprus & & & & & & & & & 2.101 & -0.048 & 0.571 & 0.488 & 2.101 & -0.026 & 0.558 & 0.506 \\
\hline Czech Republic & & & & & & & & & 0.732 & -0.045 & 0.227 & 0.060 & 0.732 & -0.047 & 0.227 & 0.062 \\
\hline Estonia & & & & & & & & & 4.889 & 0.010 & 1.238 & 2.639 & 4.889 & 0.019 & 1.233 & 2.738 \\
\hline Hungary & & & & & & & & & 1.270 & -0.031 & 0.354 & 0.179 & 1.270 & -0.038 & 0.357 & 0.185 \\
\hline Latvia & & & & & & & & & 2.196 & -0.047 & 0.594 & 0.533 & 2.196 & -0.029 & 0.584 & 0.553 \\
\hline Lithuania & & & & & & & & & 0.949 & -0.015 & 0.266 & 0.100 & 0.949 & 0.004 & 0.256 & 0.104 \\
\hline Malta & & & & & & & & & 3.004 & -0.017 & 0.781 & 0.997 & 3.004 & -0.040 & 0.791 & 1.034 \\
\hline Poland & & & & & & & & & 0.797 & 0.002 & 0.220 & 0.071 & 0.797 & 0.007 & 0.216 & 0.074 \\
\hline Romania & & & & & & & & & 3.374 & -0.047 & 0.888 & 1.257 & 3.374 & -0.049 & 0.888 & 1.304 \\
\hline Slovakia & & & & & & & & & 3.359 & -0.044 & 0.883 & 1.246 & 3.359 & 0.009 & 0.855 & 1.293 \\
\hline Slovenia & & & & & & & & & 1.116 & 0.035 & 0.283 & 0.138 & 1.116 & 0.036 & 0.281 & 0.143 \\
\hline \multicolumn{17}{|l|}{$E U-27$} \\
\hline (mean) & & & & & & & & & 1.692 & 0.039 & 0.425 & 1.175 & 1.692 & 0.041 & 0.423 & 1.219 \\
\hline Croatia & & & & & & & & & & & & & 6.634 & -0.042 & 1.699 & 5.041 \\
\hline Turkey & & & & & & & & & & & & & 10.275 & 0.096 & 2.541 & 12.093 \\
\hline $\begin{array}{c}E U-29 \\
\text { (mean) }\end{array}$ & & & & & & & & & & & & & 2.159 & 0.040 & 0.540 & 1.726 \\
\hline
\end{tabular}

$C_{i}$ is real final consumption expenditure per capita of each country and $C_{T}$ group-wide real final consumption expenditure per capita.

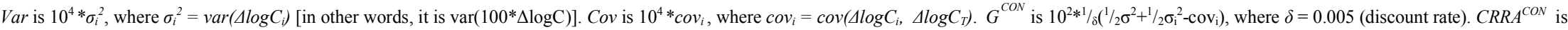
$10^{2 *}\left[\log \left(\delta-(1-\gamma) \mu-1 / 2(1-\gamma)^{2} \sigma^{2}\right)-\log \left(\delta-\left(\mu-\gamma \mu{ }^{1} / 2 \sigma_{i}^{2}+{ }^{1} / 2 \gamma^{2} \sigma^{2}-\gamma \operatorname{cov}_{i}\right)\right)+{ }^{1} / 1-\gamma \log \left(\delta-(1-\gamma) \mu-1 / 2(1-\gamma)^{2} \sigma_{i}^{2}\right)-{ }^{1} / 1-\gamma \log \left(\delta-(1-\gamma) \mu-1 / 2(1-\gamma)^{2} \sigma^{2}\right)\right]$, where the risk aversion parameter is $\gamma=3$ and the growth rate of group-wide consumption, $C_{T}$, is $\mu=0.003$. 